\title{
A Study on Fresh and Hardened Properties of Concrete with Partial Replacement of Bottom Ash as a Fine Aggregate
}

\author{
I. Ramana ${ }^{1, a}{ }^{*}$, S. Venkatachalam ${ }^{2, b}$, K. Vishnuvardhan², Dr. M.M. Saravanan ${ }^{3}$ \\ ${ }^{1} P G$ Student, Department of Civil Engineering, Kongu Engineering College, Perundurai, Erode, \\ Tamil Nadu, India \\ ${ }^{2}$ Assistant Professor, Department of Civil Engineering, Kongu Engineering College, Perundurai, \\ Erode, Tamil Nadu, India \\ ${ }^{3}$ Associate professor, Department of Civil Engineering,Vivekananda College of Technology for \\ Women, Tiruchengode, TamilNadu,India \\ aramanashri97@gmail.com, bbsvvenkat@gmail.com
}

Keywords: Concrete, Bottom Ash, Industrial Waste, Fresh Properties, Hardened Properties, Durability

\begin{abstract}
To overcome the shortage of natural resources for the production of concrete, many waste materials are used to replace the raw materials of concrete. In this way, bottom ash is one of the major industrial wastes which shall be used as the replacement of materials in concrete production. It shall be used to replace the materials either up to one-third. This review brings out the evaluation of the industrial waste material which can be repeatedly used as a substitution for concrete as fine aggregate. This paper reviewed the use of industrial waste i.e., bottom ash as fine aggregate in the concrete. The parameters discussed were physical, chemical, fresh, and hardened properties of the concrete with partial replacement of bottom ash. By reviewing some of the research papers, concluded that $10-15 \%$ replacement of fine aggregates is acceptable for all the properties of concrete. High utilization of natural sources -gives the pathway to produce more industrial wastes which are responsible for the development of new sustainable development.
\end{abstract}

\section{Introduction}

The concrete production has a large amount of negative thoughts in the field of environment and globe .Concrete is one of the most used and widely manufactured material in the world. Concrete mainly derieved from fine aggregate, cement and sand [1]. Out of these material cement is the major part of concrete which acts as a unaltered material in the field of construction.Concrete is produced by burning of natural materials like fly ash and slag of industrial by products, limestone and clay [2].Concrete is one of the major production material in the world due to its cost effectiveness, long term performance and easy application [3].Concrete is mainly used in the construction of parking garges, offshore structures railway bridges in large numbers. The reinforcement of concrete structures, in particularly in bridges is one of the key to face difficulties during their service time in front of multinational structural engineers [4]. Such concrete structures as consequence due to ineffective loads and decay corrosion .In addition most of the concrete structures were constructed during the year of 1950s and 1960s which is incompatible with current requirements[5].In concrete structures the increased in fatigue is normally subjected to millions of repetitive axle load cycles during their passive traffic during their life time that can collapse during low load limits.[6]..The main exposure of the concrete structures is fire poses. The properties of concrete includes durability ,mechanical and physical is the major effect of fire production in concrete. The mechanical characteristics of concrete are most significant during the

(c) (1) Content from this work may be used under the terms of the Creative Commons Attribution 3.0 license. Any further distribution of this work must maintain attribution to the author(s) and the title of the work, journal citation and DOI. Published under license by Materials Research Forum LLC. 
fire exposure. The endurance quality of concrete cannot be determined in any situation. The investigation of concrete has been founded that the properties of concrete affect the fire properties of concrete which include additives, industrial wastes, and types of aggregate[7]. The longiviety of concrete is not only for the structures to perform well but also for the mechanical requirements. concrete can be able to avoid more damage to structures and also withstand durability is often gives importance from the engineers. Concrete is a mixture of aggregate, cement and the water. Concrete can be able to withstand equal distribution to reduce the risk of separation of compatibility and the workability as per the building codes and the standards the concrete can be able to withstand heavy loads sufficiently. To attain the strength of concrete curing of 28 days is required. Concrete can be able to produced all degradation process which produced as a result of constituent materials[8]. To reduce the disadvantages of concrete nonmetallic reinforcement become feasible which acts substitute for the conventional concrete reinforcement[9].To maintain stable growth and safe functional environment concrete plays an important role in the field of civil engineering.[10].In order to stabilize the stability of concrete to maintain the aim of concrete waste. The main aim of the concrete is to examine the flexural properties of concrete waste[11].

The bottom ash can be obtained from the cold-fired plants that can be used as a by- product. During the ignition process the ash is softened as a result the large particles is produced and the displacement in water vessel beneath the surface of the material these large particle obtained is bottom ash.[12]. The generation of industrial waste is produced tons of bottom ash in millions. The control technique for municipal and the industrial solid waste is commonly done by using energy recovery with the incineration process. In swedoon the bottom ash gives rise to the production of just about one million tone wastes burned annually. In Switzerland and Norway the production of bottom ash is just about 18 million ton annually[13]. In similar the bottom ash can be used fpr many construction purpose after treatment. In general the treatment process involves dividing the metal pieces which goes along with the natural weathering(ageing) to produce the bottom ash more secure to filter metal by means of sparkle.[14].Bottom ash gives up the possibility of burning up of heavy metals hence suitable pre-processing before it can be applied landfilled or it can be used as a supporting raw material. Although the direct reuse of bottom ash is not achievable and it is durable and maintain the stable cost and economic benefits from using alternative material for bottom ash. The building construction produces an outstanding results for utilization of exactly treated as bottom ash[15]. Depending upon the preparation of the aggregates can be used in the form of bottom ash in the bottom of bottom of the road and in the production concrete is replaced by the natural aggregates because of pozzolanic characteristics[16]. To find the quality of bottom ash we have to concentrated on two mix design foremost one is W/c ratio and second important is stable slump value. It has been observed the exact compressive strength, drying shrinkage, and wc ratio bottom ash is increased with decreases when it mixed with concrete. In other hand in constant slump there is an equivalent amount of compressive strength mixes with concrete. The drying shrinkage enlarge when the increased natural sand is replaced by bottom ash with $30 \%[5]$. The bottom ash concrete reveals good dimensional concrete, better water resistance to sulphuric acid and chloride particles with the comparision of traditional concrete[17].[18] observed when the high strength of concrete with chloride content is replaced by fine bottom ash with fine aggregate finally the outcome shows the chloride diffusion is reduced in the presence of high concrete strength in the bottom). 


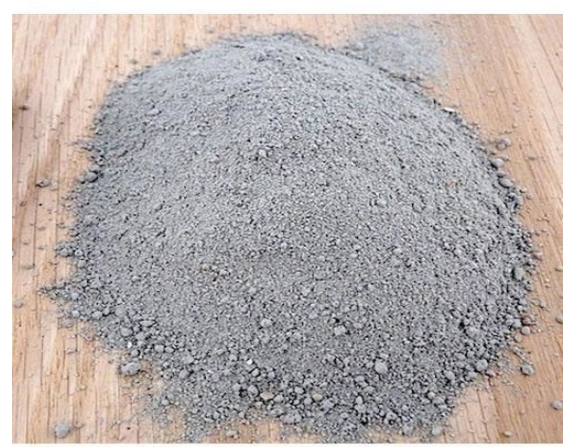

Figure:1.Bottom Ash

\section{Properties of concrete:}

In major the properties of concrete can be classified into two major parts they are

Fresh concrete

Hardened concrete

\subsection{Properties of fresh concrete}

\section{Workability}

In fresh concrete the workability is complex property which involve the various needs of strength portability, cooperative, finishability and the placeability. The best method to find suitable workability or consistency of concrete is slump cone test. The appearance of excellent waste of bottom ash in concrete gives rise to grow up the demand of concrete when contrast with standard sand particles. To maintain the standard values of workability in slump cone test the water content was slowely increased when the replacement of sand is increased with waste factory and bottom ash which gives an clear explanation about the demand of water[19].

\section{Density}

The thickness of the concrete is reduced with the enlargement of low content due to the presence of bottom ash in the relative density of bottom ash. The analysis shows due to the low content of specific gravity in bottom ash the density of concrete is less. The thickness of the concrete is reduced in hardened state with gradual increase in the bottom ash [20].

\subsection{Properties of hardened concrete}

The concrete has various properties among them strength are the most important properties. To find strength some of the test are discussed

\section{Compressive strength}

Split tensile test

Compressive strength test

Flexural strength test

The compressive strength is decreased when the concrete is mixed with the involvement of bottom ash as the substitution of particular sand. The mixture with restore fine aggregates has little difference when compared to the mix with age of 365 days[21]. The strength variation is observed due to the formation of same properties of bottom ash[22]. The development of concrete strength is increased when we added bottom ash. During the 7 days of curing the bottom ash has gained its strength as $5 \%$ and $20 \%$ which is greater than the control specimen at the level of $10 \%$ and $15 \%$ correspondingly this is due to the action of pozzolanic reaction of the bottom ash. Due to the 
substitution of bottom ash the porosity of concrete is increased. Due to the presence of silica jel in the bottom ash the $\mathrm{C}-\mathrm{S}-\mathrm{H}$ is produced the strength is increased due to the presence of jel[23].

Split Tensile Test

When the sand is replaced with bottom ash in split tensile test has less strength when compared to control concrete specimen in all the ages. Bottom ash produces split tensile strength approximately ranges from $121-126 \%$ at 90 days of the normal concrete at 28 days.[24].The substitution of bottom ash in concrete the strength is increased at 7 days and 28 days is the most perfect one. The workability of concrte is reduced when the bottom ash is added as a fine aggregate[25].In 7, and 28 days the split tensile test is increased for $10 \%$ to $30 \%$ replacement in remaining substitution the split tensile test was decreased[26].In 7 days the split tensile test was increase at the ratio of $0.7 \%, 5.70 \%$ and $12.16 \%$ for 10,20 and $30 \%$ of substitution. For the substitution of $50 \%$ there is a dropping of $15.20 \%$ at the curing of 7 days. During the replacement of 20 and $30 \%$ the strength of the split tensile test in increased in 28 days of curing[27].

Flexural Strength Test

The difference in the strength between bottom ash and normal concrete become less clear after 28 days. The substitution of fine aggregates in the flexural strength the concrete is proceed to extend with all the ages of bottom ash .The adding of $30 \%$ of bottom ash with concrete and sand the strength of the flexural properties is high. It is observed that the flexural strength of concrete is about linearly decreased when the substitution level of bottom ash is increased[20].

\section{Physical characteristics of commercial waste as fine aggregate}

Physical characteristics of construction waste includes particle size distribution, thickness specific gravity absorption and fine substances helps to realize its ability and the workability when the concrete is replaced by fine aggregate.

Some of the physical charecteristics are:

Specific Gravity

Water Absorption

Bulk Density

Shape and Appearance

Particle Size Distribution

\subsection{Specific gravity}

Different investigators have been observed that the specific gravity of some of the industrial waste substances are discussed below. The bottom ash has the SG lies between 1.39 and 2.33[35] when compared to the specific gravity is in between 1.93,1.39 and 1.87[36]. The specific gravity of unused manufactured sand was investigated to be 2.18.It has been clearly investigates that the specific gravity of waste manufacturing sand ranges from 2.39-2.79.[37] The specific gravity of steel slag is $3.15[38]$.

\subsection{Water absorption:}

It is studied that the absorption of water in $\mathrm{BA}$ is $5.4 \%$ and $6.1 \%$ respectively[42]. The water absorption present in the waste manufacturing sand is $1.2 \%$.[29] The absorption of water in copper slag is $0.17 \%[43]$.The absorption of water in GGBS was found to be $10.0 \%[15]$. The presence of water content in steel salg is $0.80 \%[13]$

\subsection{Bulk density}

The bulk density of bottom ash is $660 \mathrm{~kg} / \mathrm{m} 3[28]$ when it is differentiated to the loose density of BA is $620 \mathrm{~kg} / \mathrm{m} 3$ [31].The compacted bulk density of manufacturing sand is $1890 \mathrm{Kg} / \mathrm{m} 3[39]$ while the loose density of the manufacturing sand is $1690 \mathrm{Kg} / \mathrm{m} 3$. .[37]. The density of copper slag 
varies from $1900 \mathrm{~kg} / \mathrm{m} 3$ to $2150 \mathrm{~kg} / \mathrm{m}$.[40]. The unit weight of copper slag is $2395 \mathrm{Kg} / \mathrm{m} 3$ and the packing thickness of copper slag is $1475 \mathrm{~kg} / \mathrm{m} 3[41]$

\subsection{Shape and appearance}

Bottom ash have the rough quality and sharp, uneven and porous material it is well placed sand sized material. The bottom ash has black to grey colour. The liquid content of the bottom ash ranged from 70 to $80 \%$ of the ash in the presence of dry weight[28].Generally manufacturing sub-rakish sand in the form of spherical in shape. Foundry sand are grey or dark while chemical manufacturing sand are grey in colour[29]. IFS slag is dark in Colour, it is granular and vitreous and it carry toxic metal[30]. The copper slag is powdered and dark in nature, shiny particles .The particle size distribution is same as normal sand[31].

\subsection{Particle size distribution}

The distribution of grain size in bottom size is replaced with 55\% material then it ranges in between 1.12 and 0.16 [32]. The particle size distribution of copper slag is just about $75 \%$ particles ranges in between 0.3 and 1.18 [33].Particle size distribution is similar in foundry sand is ranges from $85-95 \%$ of the material lies between $0.6 \mathrm{~mm}$ to $0.15 \mathrm{~mm}$ and greater or smaller than $5-20 \%$ of manufacturing sand is lesser than $0.75 \mathrm{~mm}[34]$.

\section{Chemical characteristics of bottom ash as a fine aggregate}

The chemical characteristics of bottom ash is identified based upon the process of burning and the types of coal used. The BA is generally composed of aluminium ,iron and silica dueto the presence of small amount of Sulphate, magnesium and calcium.[35].

\section{Behaviour of bottom ash}

Bottom ash is produced by the incineration process of municipal solid waste management it includes combustible ash, unburned carbon and the noncombustible inorganics based on the characteristics of waste and the classification of incinerators. In common the bottom ash is produced with the mixture of boiler ash is treated with slag. After the completion of incineration process the bottom ash is produced through the furnace bottom and it need to be water-cooled before it produced.[44].

\section{Conclusion}

Utilization of various industrial waste as fine aggregate replacement was discussed. All the concrete characteristics like hard and freshened, physical were explained and compared among them. The large amount of industrial wastes are used as a partial replacement of fine aggregate like bottom ash, steel slag, copper slag, waste foundry and fly ash.

Physical properties like shape and appearance, particle size distribution, specific gravity, water absorption all the industrial wastes are nearly to the characteristics of sand excluding particle size distribution of manufacturing sand.

\section{References}

[1] Al-Jabri K S, Al-Saidy A H and Taha R 2011 Effect of copper slag as a fine aggregate on the properties of cement mortars and concrete Construction and Building Materials25 933-8. https://doi.org/10.1016/j.conbuildmat.2010.06.090

[2] Tayeh B A, Hasaniyah M W, Zeyad A and Yusuf M O 2019 Properties of concrete containing recycled seashells as cement partial replacement: A review Journal of Cleaner Production 237 117723. https://doi.org/10.1016/j.jclepro.2019.117723

[3] Jindal B B 2019 Investigations on the properties of geopolymer mortar and concrete with 
mineral admixtures: A review Construction and Building Materials227 116644. https://doi.org/10.1016/j.conbuildmat.2019.08.025

[4] Andrade L, Rocha J and Cheriaf M 2009 Influence of coal bottom ash as fine aggregate on fresh properties of concrete Construction and Building Materials23 609-14.

https://doi.org/10.1016/j.conbuildmat.2008.05.003

[5] Bai Y, Darcy F and Basheer P 2005 Strength and drying shrinkage properties of concrete containing furnace bottom ash as fine aggregate Construction and Building materials19 691-7. https://doi.org/10.1016/j.conbuildmat.2005.02.021

[6] Al-Saadi N T K, Mohammed A, Al-Mahaidi R and Sanjayan J 2019 A state-of-the-art review: near-surface mounted FRP composites for reinforced concrete structures Construction and Building Materials209 748-69. https://doi.org/10.1016/j.conbuildmat.2019.03.121

[7] Memon S A, Shah S F A, Khushnood R A and Baloch W L 2019 Durability of sustainable concrete subjected to elevated temperature-A review Construction and Building Materials 199 435-55. https://doi.org/10.1016/j.conbuildmat.2018.12.040

[8] Kanellopoulos A, Petrou M F and Ioannou I 2012 Durability performance of self-compacting concrete Construction and Building Materials37 320-5. https://doi.org/10.1016/j.conbuildmat.2012.07.049

[9] Abdulla N A 2017 Concrete filled PVC tube: A review Construction and Building Materials 156 321-9. https://doi.org/10.1016/j.conbuildmat.2017.08.156

[10] Popescu C, Sas G, Blanksvärd T and Täljsten B 2015 Concrete walls weakened by openings as compression members: A review Engineering Structures89 172-90.

https://doi.org/10.1016/j.engstruct.2015.02.006

[11] Seara-Paz S, González-Fonteboa B, Martínez-Abella F and Eiras-López J 2018 Flexural performance of reinforced concrete beams made with recycled concrete coarse aggregate Engineering Structures156 32-45. https://doi.org/10.1016/j.engstruct.2017.11.015

[12] Pormmoon P, Abdulmatin A, Charoenwaiyachet C, Tangchirapat W and Jaturapitakkul C 2020 Effect of cut-size particles on the pozzolanic property of bottom ash Journal of Materials Research and Technology10 240-9. https://doi.org/10.1016/j.jmrt.2020.12.017

[13] Devi V S and Gnanavel B 2014 Properties of concrete manufactured using steel slag Procedia Engineering97 95-104. https://doi.org/10.1016/j.proeng.2014.12.229

[14] Tiberg C, Sjöstedt C and Fedje K K 2020 Speciation of $\mathrm{Cu}$ and $\mathrm{Zn}$ in bottom ash from solid waste incineration studied by XAS, XRD, and geochemical modelling Waste Management119 389-98. https://doi.org/10.1016/j.wasman.2020.10.023

[15] Etxeberria M, Pacheco C, Meneses J and Berridi I 2010 Properties of concrete using metallurgical industrial by-products as aggregates Construction and Building Materials 24 1594-600. https://doi.org/10.1016/j.conbuildmat.2010.02.034

[16] Romero A R, Salvo M and Bernardo E 2018 Up-cycling of vitrified bottom ash from MSWI into glass-ceramic foams by means of 'inorganic gel casting'and sinter-crystallization

Construction and Building Materials 192 133-40.

https://doi.org/10.1016/j.conbuildmat.2018.10.135

[17] Singh M and Siddique R 2014 Compressive strength, drying shrinkage and chemical resistance of concrete incorporating coal bottom ash as partial or total replacement of sand Construction and Building Materials68 39-48. https://doi.org/10.1016/j.conbuildmat.2014.06.034 
[18] Kim H, Jang J G, Choi Y and Lee H-K 2014 Improved chloride resistance of high-strength concrete amended with coal bottom ash for internal curing Construction and Building Materials71 334-43. https://doi.org/10.1016/j.conbuildmat.2014.08.069

[19] Aggarwal Y and Siddique R 2014 Microstructure and properties of concrete using bottom ash and waste foundry sand as partial replacement of fine aggregates Construction and Building Materials54 210-23. https://doi.org/10.1016/j.conbuildmat.2013.12.051

[20] Nadig V R, Sanjith J, Ranjith A and Kiran B 2015 Bottom Ash as Partial Sand Replacement in Concrete-A Review IOSR Journal of Mechanical and Civil Engineering (IOSR-JMCE) e-ISSN 2278-1684

[21] Siddique R, Aggarwal Y, Aggarwal P, Kadri E-H and Bennacer R 2011 Strength, durability, and micro-structural properties of concrete made with used-foundry sand (UFS) Construction and Building Materials25 1916-25. https://doi.org/10.1016/j.conbuildmat.2010.11.065

[22] Yüksel İ and Bilir T 2007 Usage of industrial by-products to produce plain concrete elements Construction and Building Materials21 686-94.

https://doi.org/10.1016/j.conbuildmat.2006.06.031

[23] Andrade L B, Rocha J and Cheriaf M 2007 Evaluation of concrete incorporating bottom ash as a natural aggregates replacement Waste Management27 1190-9.

https://doi.org/10.1016/j.conbuildmat.2006.06.031

[24] Aggarwal P, Aggarwal Y and Gupta S 2007 Effect of bottom ash as replacement of fine aggregates in concrete

[25] Bhuvaneshwari P and Murali R 2013 Strength characteristics of glass fiber on bottom ash based concrete International Journal of Science, Environment and Technology2 90-102

[26] Kadam M and Patil Y 2013 Effect of coal bottom ash as sand replacement on the properties of concrete with different w/c ratio International Journal of Advanced Technology in Civil Engineering, ISSN 2231-5721

[27] Soman K, Sasi D and Abubaker K 2014 Strength properties of concrete with partial replacement of sand by bottom ash International Journal of Innovative Research in Advanced Engineering (IJIRAE) 2349-163

[28] Dash M K, Patro S K and Rath A K 2016 Sustainable use of industrial-waste as partial replacement of fine aggregate for preparation of concrete-A review International Journal of Sustainable Built Environment5 484-516. https://doi.org/10.1016/j.ijsbe.2016.04.006

[29] Singh G and Siddique R 2012 Abrasion resistance and strength properties of concrete containing waste foundry sand (WFS) Construction and building materials 28 421-6.

https://doi.org/10.1016/j.conbuildmat.2011.08.087

[30] Khatib J, Herki B and Kenai S 2013 Capillarity of concrete incorporating waste foundry sand Construction and building materials47 867-71.

https://doi.org/10.1016/j.conbuildmat.2013.05.013

[31] Ambily P, Umarani C, Ravisankar K, Prem P R, Bharatkumar B and Iyer N R 2015 Studies on ultra high performance concrete incorporating copper slag as fine aggregate Construction and Building Materials77 233-40. https://doi.org/10.1016/j.conbuildmat.2014.12.092

[32] Bilir T 2012 Effects of non-ground slag and bottom ash as fine aggregate on concrete permeability properties Construction and Building Materials 26 730-4.

https://doi.org/10.1016/j.conbuildmat.2011.06.080 
[33] Kou S-C and Poon C-S 2009 Properties of concrete prepared with crushed fine stone, furnace bottom ash and fine recycled aggregate as fine aggregates Construction and Building Materials23 2877-86. https://doi.org/10.1016/j.conbuildmat.2009.02.009

[34] Kaur G, Siddique R and Rajor A 2012 Properties of concrete containing fungal treated waste foundry sand Construction and Building Materials29 82-7.

https://doi.org/10.1016/j.conbuildmat.2011.08.091

[35] Siddique R 2014 Utilization of industrial by-products in concrete Procedia Engineering95 335-47. https://doi.org/10.1016/j.proeng.2014.12.192

[36] Siddique R, Singh G, Belarbi R and Ait-Mokhtar K 2015 Comparative investigation on the influence of spent foundry sand as partial replacement of fine aggregates on the properties of two grades of concrete Construction and Building Materials83 216-22.

https://doi.org/10.1016/j.conbuildmat.2015.03.011

[37] Singh G and Siddique R 2012 Effect of waste foundry sand (WFS) as partial replacement of sand on the strength, ultrasonic pulse velocity and permeability of concrete Construction and building materials 26 416-22. https://doi.org/10.1016/j.conbuildmat.2011.06.041

[38] Qasrawi H, Shalabi F and Asi I 2009 Use of low CaO unprocessed steel slag in concrete as fine aggregate Construction and Building Materials 23 1118-25. https://doi.org/10.1016/j.conbuildmat.2008.06.003

[39] Yüksel İ, Siddique R and Özkan Ö 2011 Influence of high temperature on the properties of concretes made with industrial by-products as fine aggregate replacement Construction and building materials25 967-72. https://doi.org/10.1016/j.conbuildmat.2010.06.085

[40] Wu W, Zhang W and Ma G 2010 Optimum content of copper slag as a fine aggregate in high strength concrete Materials \& Design31 2878-83. https://doi.org/10.1016/j.matdes.2009.12.037

[41] Wu W, Zhang W and Ma G 2010 Mechanical properties of copper slag reinforced concrete under dynamic compression Construction and Building Materials24 910-7. https://doi.org/10.1016/j.conbuildmat.2009.12.001

[42] Kim H-K and Lee H-K 2011 Use of power plant bottom ash as fine and coarse aggregates in high-strength concrete Construction and Building Materials25 1115-22.

https://doi.org/10.1016/j.conbuildmat.2010.06.065

[43] Velumani M and Nirmalkumar K 2014 Durability and characteristics of copper slag as fine aggregate and fly ash as cement in concrete. In: Second International Conference on Current

Trends In Engineering and Technology-ICCTET 2014: IEEE) pp 222-7.

https://doi.org/10.1109/ICCTET.2014.6966291

[44] Youcai Z 2016 Pollution control and resource recovery: municipal solid wastes incineration: bottom ash and fly ash: Butterworth-Heinemann) 